\title{
PROBLEMS IN THE USE OF LOCAL SIGNIFICANCE ROADS: A CASE STUDY OF ŠIAULIAI DISTRICT KAIRIAI ELDERSHIP
}

\author{
Virginija ATKOCEVIČIENĖ, Department of Land Use Planning and Geomatics, Faculty of Engineering, Vytautas Magnus \\ University, K. Donelaičio g. 58, LT-44248 Kaunas, Lithuania, virginija.atkoceviciene@ vdu.lt \\ Jolanta VALČIUKIENĖ, Department of Land Use Planning and Geomatics, Faculty of Engineering, Vytautas Magnus University, \\ K. Donelaičio g. 58, LT-44248 Kaunas, Lithuania, jolanta.valciukiene@ vdu.lt (corresponding author) \\ Daiva JUKNELIENĖ, Department of Land Use Planning and Geomatics, Faculty of Engineering, Vytautas Magnus University, \\ K.Donelaičio g. 58, LT-44248 Kaunas, Lithuania, daiva.jukneliene@ vdu.lt \\ virginija.atkoceviciene@vdu.lt
}

Dovydas LIVANAS, Department of Land Use Planning and Geomatics, Faculty of Engineering, Vytautas Magnus University, K. Donelaičio g. 58, LT-44248 Kaunas, Lithuania,

\begin{abstract}
A road is an engineering structure that performs a very important purpose of transportation. Roads are divided into categories that stand out for their importance and significance. One such category is local roads, which are classified in the lowest category. The most common problems that arise with these roads are that on this category ${ }^{\text {of }}$ roads due to low traffic, road maintenance is simply not carried out or many such roads are not registered with the State Enterprise Center of Registers, resulting in changes in road boundaries when forming adjacent plots. Discrepancies in the use of local significance roads are observed as well during road cadastral measurements and the preparation of cartographic material. The aim of this article is to analyze the problems of local road use in Šiauliai district Kairiai eldership. The analyzed topic is new, little studied in the domestic and foreign literature, but it is very relevant in production, therefore there is a need to analyze and identify the problems of the use of local significance roads in more detail. During the research, the special plan of the communication system of Kairiai eldership, land management plans and orthophotographic maps were examined. It has been established that Kairiai eldership is classified as a suburban area, which is likely to affect the growth of the local road network, which currently amounts to $120 \mathrm{~km}$. A detailed analysis of the lengths of local roads in Kairiai eldership revealed that the entire network makes up 37 per cent of public roads, 36 per cent of streets and 27 per cent of internal roads. The majority (more than $15 \mathrm{~km}$ ) of local significance internal roads are made up of gravel pavements. After the cadastral measurements, analysis of territory planning documents and other planned material, it was established that 29 local significance roads were not registered in Kairiai eldership, and instead of the indicative length of $20.8 \mathrm{~km}$ of these roads, only $16.7 \mathrm{~km}$ were identified, i.e. $4.1 \mathrm{~km}$ discrepancy/deficiency detected. Also, during the study, the analysis of territory planning documents and other primary planning material revealed that the following problems of road use are most common: poor road maintenance, improper road use, selfish connection of the road to the existing land plot and road interference with private land plots. In order to avoid certain identified problems, it would be appropriate to set up a kind of monitoring system that would allow the condition of the roads to be monitored and contribute to the planning of their management. It is also very important to oblige landowners to use existing land plots in an orderly manner. Local road management plans are needed with increased funding as well as obliging landowners to use and maintain their land properly.
\end{abstract}

Keywords: local significance road, cadastral measurements of land plots, territory planning documents

\section{INTRODUCTION}

The road is an engineering structure, the design requirements of which must be taken into account at all stages of design, as well as the solutions of territory planning documents. Before road construction or reconstruction works, it is necessary to perform geodetic, hydrological, geological and existing pavement structure research (Order of the director..., 2016). After careful road design work, detailed analysis of the condition of the area and the current situation, it is even possible to avoid environmental pollution. Most often, pollution levels rise in areas where roads are in the wrong location, poorly maintained or constructed (Keller, Sherar, 2003).

According to the data of the Road Administration, there are almost 64 thousand kilometers of local significance roads in Lithuania. These roads consist of asphalt, gravel, and paved roads. The biggest problems are paved roads, because, they have neither a pavement nor a road base and no longer serve the purpose of the road. According to municipal data, paved roads make up 19 per cent of all local significance roads, 63 per cent are gravel roads and 18 per cent are asphalt roads (Kryževičienè, 2016).

Copyright (C) 2021 The Authors. Published by Vytautas Magnus University. This is an open-access article distributed under the terms of the Creative Commons Attribution License (CC BY 4.0), which permits unrestricted use, distribution, and reproduction in any medium, provided the original author and source are credited. 
In Lithuania, in terms of history, six stages of road development can be seen. In the latter stage, i.e. at present, the road network in the country has significantly improved, many more asphalt roads have appeared, and recreation areas, hotels, cafes, gas stations and other zones have appeared in roadside areas (Petkevičienè and Petkevičius, 2006; Tamošauskas, 2008; Sivilevičius, 2012). When forming land plots, it is important for land use planners to take into account that the road should be as short as possible, use existing roads and their equipment, not divide land plots into narrow areas. Later, when operating the roads, it is necessary to observe the protection zones, the road must be formed by comparing all possible variants and calculating all costs, choosing the most optimal variant (Aleknavičius, 2017).

Geodetic measurements are very important for road design and construction, this process is the starting point from which road formation begins (Skeivalas, 2006; Paršeliunas et al., 2008; Aleknavičius, 2012; Moser et al., 2016). The most popular measurement method is using a GPS receiver, another method would be using an electronic tacheometer, and the least used are drones, the prices of which are still high.

When performing cadastral measurements and preparing a land plot plan and forming a cadastral data file, everything must be coordinated with the division of the National Land Service under the Ministry of Agriculture, then everything must be submitted to the State Enterprise Center of Registers to the real estate cadastre manager. The boundaries of the plot of land and the turning points between them must form a single object. Roads that intervene in the land plot must be formed as separate areas (Aleknavičius, 2012).

When performing cadastral measurements of agricultural land plots, it is often recorded that the adjacent roads, their protection zones move away from the plot or no longer correspond to the purpose. This is due to the fact that heavy agricultural machinery destroys these objects. As a consequence, the shapes of the roads change, they interfere with other plots of land and protection zones (Gasilionis, 2001). Other possible deforming factors of the road can be changes in temperatures and melting snow in the spring, which, when turned into water, worsens the structure of the road surface (Sivilevičius, Sokolov, 2011).

The aim of this article is to analyze the problems of the use of local significance roads in Kairiai eldership of Šiauliai district. To achieve this goal, the following tasks have been set: 1 . To analyze the general characteristics of the local significance road network in Šiauliai district and Kairiai eldership. 2. Using the data collected during cadastral measurements, identify problems in the use of local significance roads.

\section{MATERIALS AND METHODS}

During the research, the analysis of literature sources and territory planning documents and other planned material was performed. Statistical information on the characteristics of the local road network was collected from the solutions of the Šiauliai District Special Plan communication system, the Statistics Department and various orders of the Road Administration. During the research, the data of the real estate register subsystem "GeoMatininkas" of the State Enterprise Centre of Registers were also used, which allowed to examine the location of land plots. With the help of this subsystem, it was determined whether the roads enable all land users to access the land they use. During the graphical modeling, the results of field cadastral measurements (obtained using a GPS receiver) were processed using the Geomap software, which were also compared with orthophotographic maps published on the Lithuanian Spatial Information Portal (www.geoportal.lt). During the analysis, the condition of the researched roads and their discrepancies with the territory planning documents or other planned material were determined. After analyzing and summarizing the obtained research results, the conclusions and suggestions were presented.

The Kairiai eldership of Šiauliai district was chosen as the object of research. In general, Šiauliai district belongs to Šiauliai County, which is located in the northern part of Lithuania. The district consists of 11 elderships. Kairiai eldership is located in the eastern part of the district and consists of five elderships, which include 26 settlements (Figure 1). This eldership is distinguished by the fact that it is close to the city of Šiauliai and due to urbanization factors it is classified as a suburban area, for which a well-developed road network should be one of the most important factors.

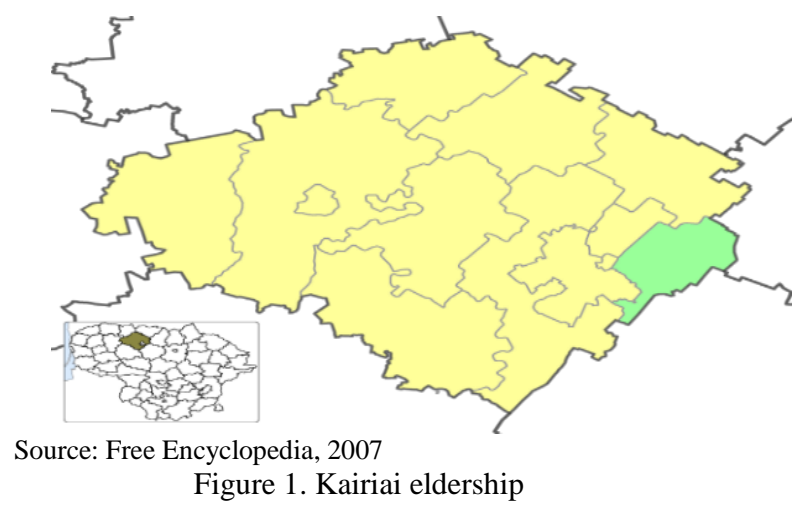

According to the data of the Land Fund of the Republic of Lithuania, in 2020 Kairiai eldership covered 9029.04 ha, of which as much as 74 per cent were occupied by agricultural land, 12 per cent - by forests, 4 per cent - by built-up areas, 5 per cent - by water bodies, 3 per cent - by other land and only 2 per cent - by roads. Thus, as can be seen, the 
roads occupied a relatively very small part of the eldership. Therefore, it is important to review their condition or possible problems in use, in order to achieve the best possible and already rather unsuitable development of the road network.

\section{RESULTS}

When examining the local significance road network, it is important to take into account the fact that these roads are divided into public, street and internal roads. Public roads are owned by municipalities. Internal roads can be owned by the state, municipalities or even natural and/or legal persons. The purpose of local significance roads is to provide access to local people. Without these roads, it would not be possible to reach district and other roads or various residential areas.

The strategic development plan of Šiauliai district municipality in 2017-2023 provided for the improvement of the condition of local significance roads, streets, pedestrian and bicycle paths, the acquisition of ecological vehicles and the promotion of public use (Šiauliai district..., 2016).

The length of local roads in all 11 Šiauliai district elderships is $1949 \mathrm{~km}$. Public roads cover $575.9 \mathrm{~km}$, which is 31 per cent of all local roads, $602.2 \mathrm{~km} \mathrm{(30 \% )} \mathrm{of} \mathrm{Internal} \mathrm{roads} \mathrm{and} 770.5 \mathrm{~km} \mathrm{(39 \% )} \mathrm{of} \mathrm{streets} \mathrm{(Figure} \mathrm{2).}$

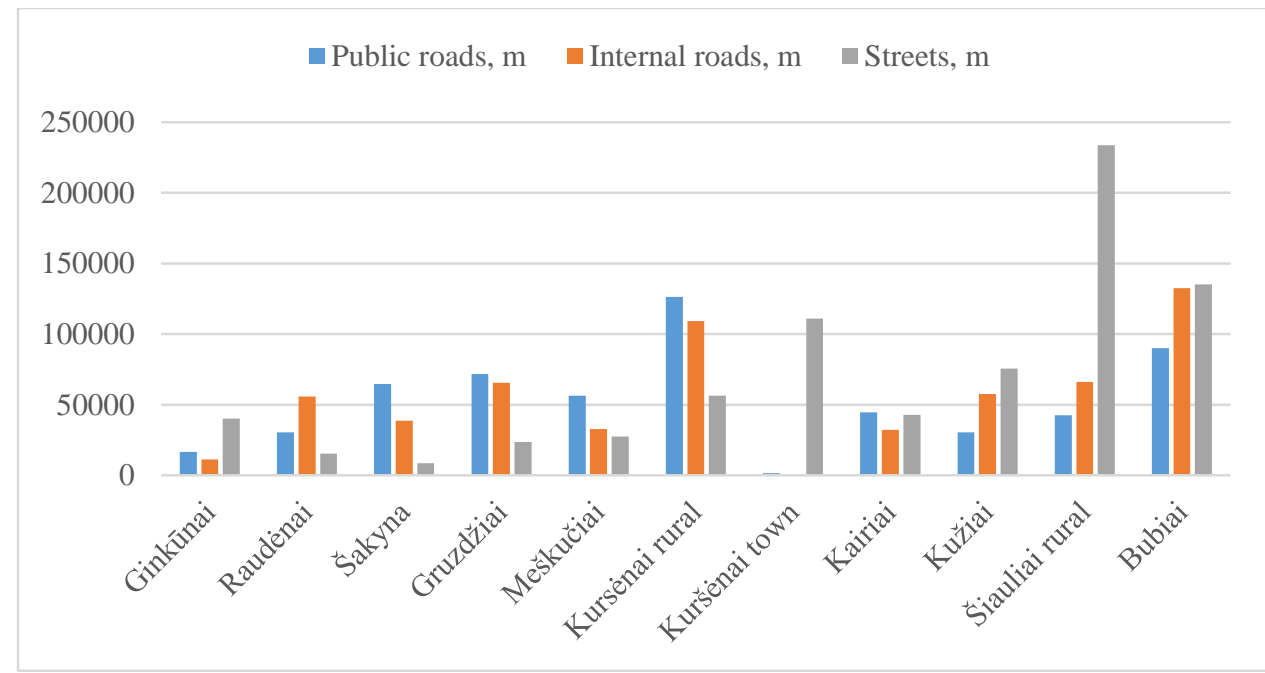

Source: Adjustment of the special..., 2018a

Figure 2. Distribution of public, internal roads and streets of Šiauliai district elderships by length in $\mathrm{m}$

In Šiauliai district, the network of local roads with streets is evenly distributed, except for Kuršenai city and Šiauliai rural elderships. Kuršènai city eldership has no internal roads, and public roads are only five, the total length of which is $1.59 \mathrm{~km}$, but the length of all streets is $111.1 \mathrm{~km}$. Šiauliai rural eldership stands out as an eldership, where the length of all streets is the longest in the district and makes up as much as $223.7 \mathrm{~km}$.

The local road network of Kairiai eldership with public internal roads and all streets of $120 \mathrm{~km}$ is analyzed in detail in the study, of which the majority (37\%) is occupied by public roads (Figure 3). Basically, public roads are like a business card of settlements, their condition shows whether the funds allocated for road maintenance are absorbed properly. Roads of the above category are used the most, as they allow access to district roads, connecting streets.

According to the adjustment solutions of Šiauliai district of the Transport System Special Plan, the local significance Internal roads of Kairiai eldership are $32.17 \mathrm{~km}$ long, of which $6.90 \mathrm{~km}$ are asphalt roads, $15.80 \mathrm{~km}$ are gravel roads, and $9.47 \mathrm{~km}$ are paved roads. There are 38 local significance internal roads in the eldership. Their condition is very diverse, the best roads are in the first and second categories, the worst are in the third category.

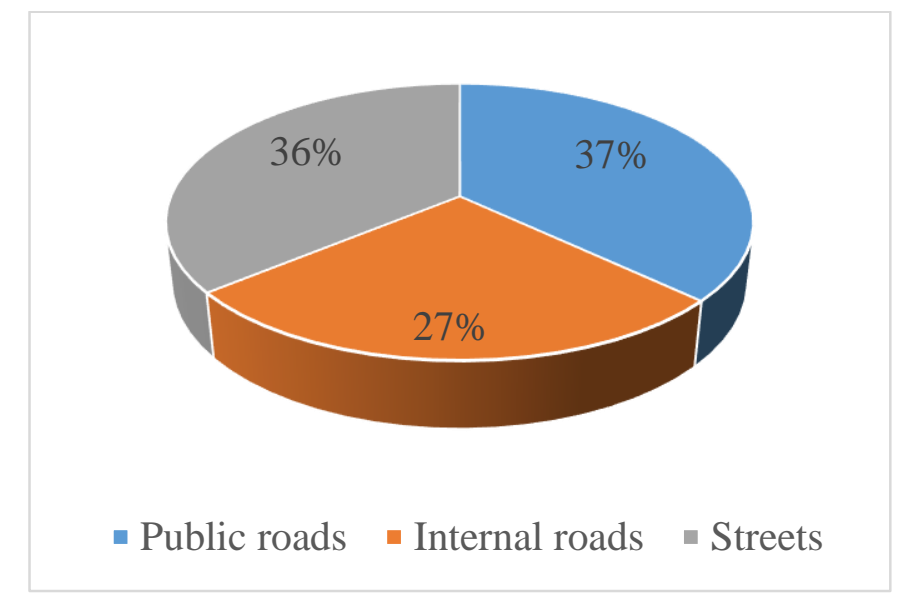

Source: Adjustment of the special plan..., 2018b 
Figure. 3 Percentage distribution of public, internal roads and streets of Kairiai eldership by length in km

Local roads must be designed to connect with state roads. Access to real estate, common areas, natural, historical and cultural sites is included in the local road network. However, these roads are designed only when they allow access to 5 or more plots of land, otherwise an easement is designed.

During a detailed research of the internal roads of Kairiai eldership of Šiauliai district, it became clear that the condition of most roads is poor. Many of them are rarely used, as can be seen from the overgrown vegetation in the roadway. This trend is most often observed on roads that do not have slopes and embankment (Figure 4).

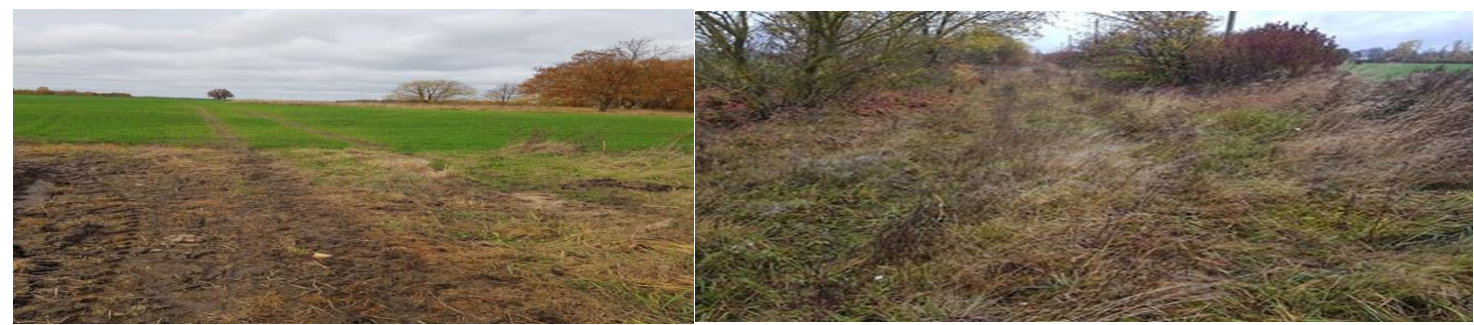

a)

b)

Figure 4. Kairiai eldership road no. 04-011 (a) and no. 04-007 (b) excerpts (photograph by the authors).

As can be seen, road no. 04-011 was used mostly by heavy agricultural machinery. Another big problem is that the road has neither a slope nor embankment, which makes it overgrown with grass. In addition, it can be seen that the owner of a plot of land adjacent to the road has plowed it up and thus formed a larger plot of land, without taking into account the interests of the other owners of the plots of land. Such unattended roads deform very easily. The analysis also revealed another problem of local significance road use affecting poor road condition, namely road slopes and culverts that are overgrown with vegetation. These parts of the road are very important for maintaining good condition, because, with their help, water is drained from the roadway. While driving heavy machinery, the situation worsens and the roadway tends to deform (Figure 5).

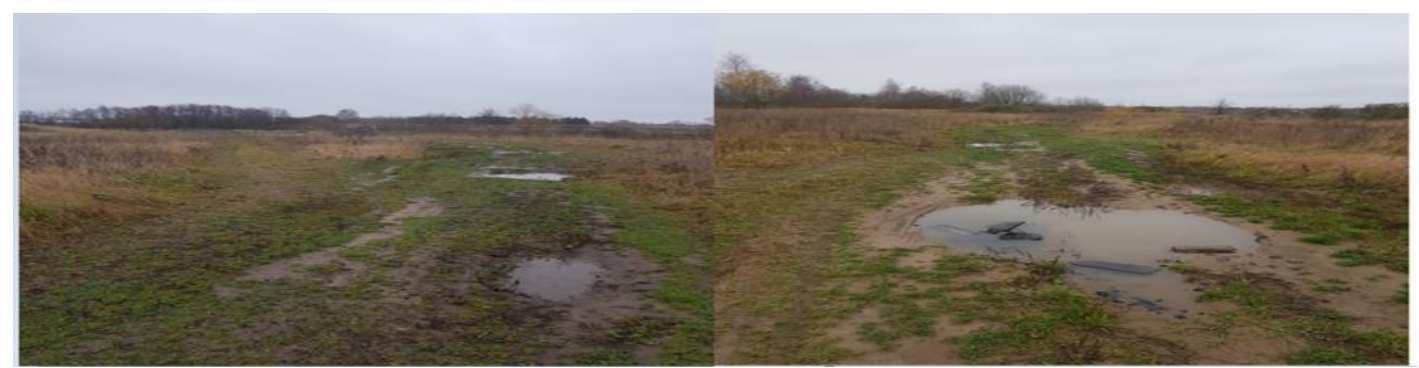

Figure 5. Road no. 04-033 excerpts (photography by the authors)

The study also found that in the presented figure, the road is very winding, although according to the planning rule it should be straight. This was most likely due to an attempt to bypass the formed pits. This led to even greater changes in road contours.

During the research, it was noticed that the local roads of Kairiai eldership, which are near more important objects or more often used, are in very good condition. The main road A9 crossing Kairiai eldership is also likely to have a significant impact on this (Figure 6).

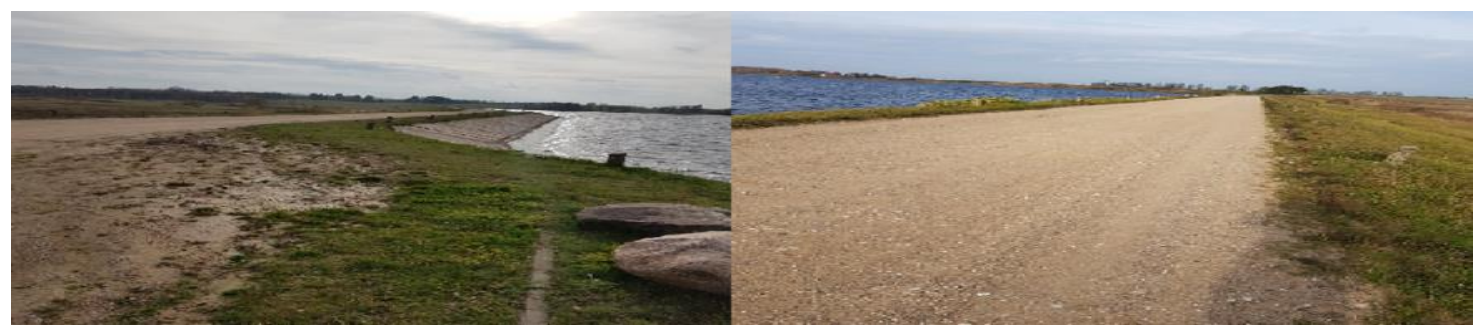

Figure 6. Road no. 04-031 excerpts (photography by the authors)

Tourists passing this road often stop to admire the beautiful lake landscapes that the village of Kairiai is famous for. The path shown in Figure 6 is an example of excellent maintenance. It is located near Lake Gudeliai, so it is maintained and is in excellent condition.

During the cadastral measurements, frequently recurring road formation problems were observed, which are relevant not only to Kairiai eldership, but also to the entire Lithuanian local road network. One of the most common problems is discrepancies of several lengths when comparing municipal data with the situation in kind. Cadastral measurement works were performed on unregistered local significance roads in Kairiai eldership. After processing the 
results of cadastral measurements, the actual lengths of internal roads were obtained, which differ significantly from the data available to the municipality (Figure 7).

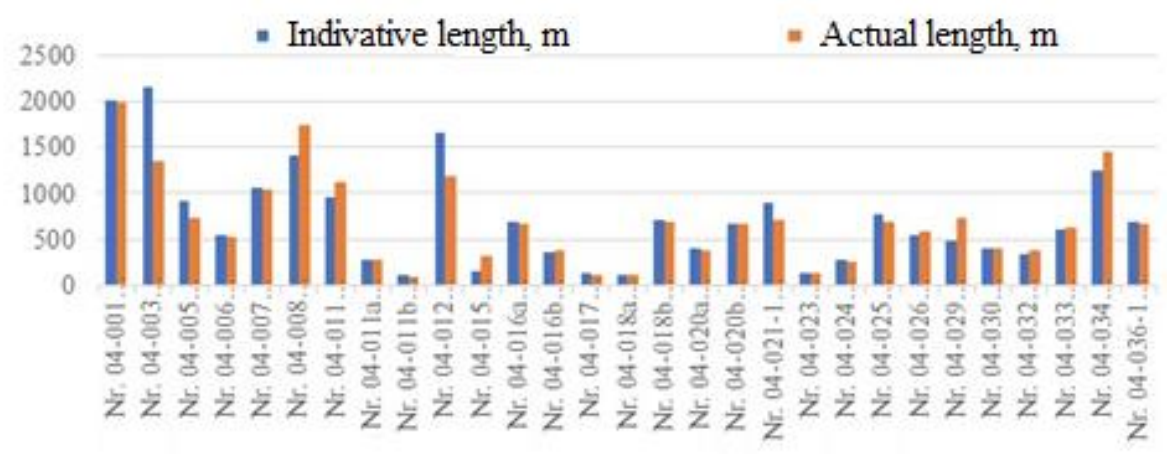

Number of the road

Compiled by the authors, source: Adjustment of the special plan..., 2018b

Figure 7. Comparison of unregistered internal road lengths of Kairiai eldership with the results of cadastral measurements

During the research, it was established that 29 local significance roads were not registered in Kairiai eldership. After performing cadastral measurements and drawing plans, it became clear that according to the municipal data, the total reference length of these roads should be about $20.8 \mathrm{~km}$, and is $16.7 \mathrm{~km}$, i.e. a discrepancy of $4.1 \mathrm{~km}$ was detected.

The study also identified another relatively common problem with the use of local significance roads, which is the intrusion of poorly maintained roads into registered plots of land. In such cases, the roadway usually separates from the area it forms. The reasons for this deformation can be various: poor road construction, poor maintenance, improper operation of agricultural machinery. Particular attention is paid to changes in turns, i.e. the road changes so that in the bend of the road it intervenes in the plots of land. Such a situation was observed on Kairiai eldership road no. 04-007 (Figure 8).

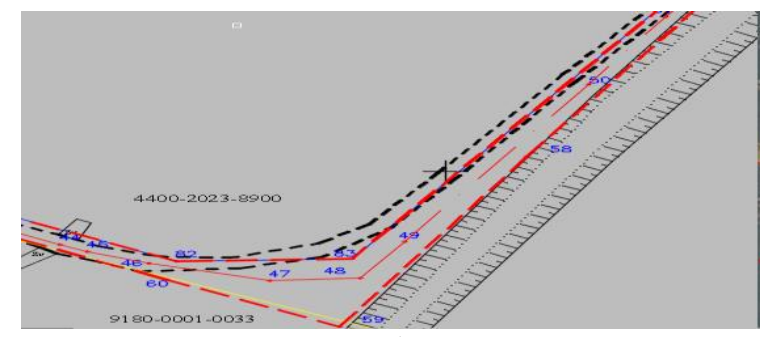

a)

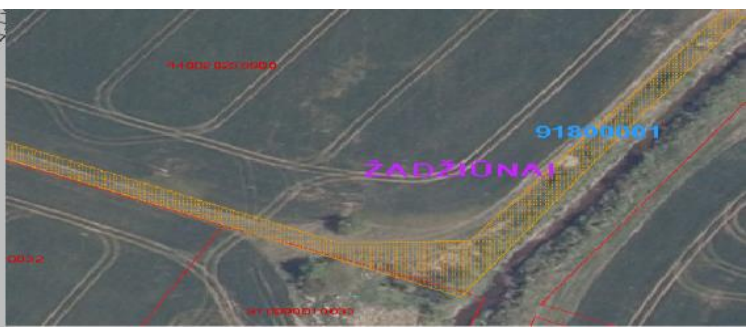

b)

Source: $\underline{w w w . g e o p o r t a l . l t}$

Figure 8. Road no. 04-007 cadastral measurement results (a) and orthophoto (b)

The presented fragment shows that the road zone was formed according to the adjacent registered land plots. However, the real road situation does not correspond at all to the layout of the zone. This means that since the cadastral measurements of the field were carried out on the adjacent plots of land, the real situation has changed significantly. An identical example of such a situation was recorded and on the road no. 04-011 (Figure 9).

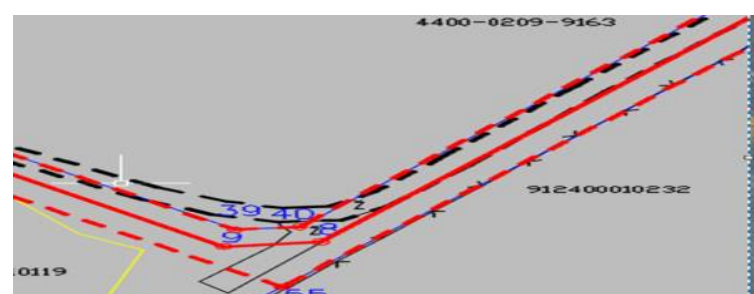

a)

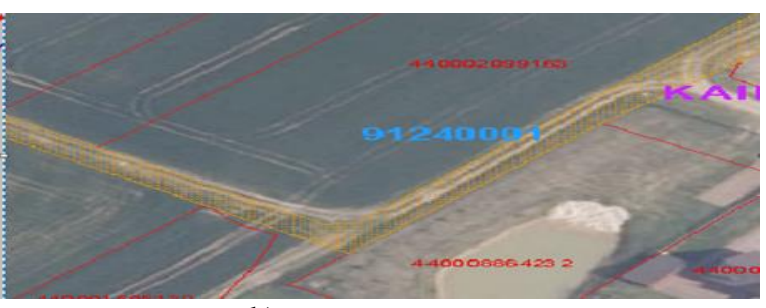

b)

Source: www.geoportal.lt

Figure 9. Road no. 04-011 results of cadastral measurements (a) and orthophoto (b)

These reviewed examples, as well as the cadastral measurements and inventory performed during the research, allow determining which roads need repair. As can be seen, the deformations are not significant and are not likely to cause major difficulties for land users, but this is a major problem in the formation of land plots leading to discrepancies between the available initial planning material or other data and the actual situation.

The study also found that adjacent plots of land have a significant impact on the formation of the road zone, but there are cases where arbitrary behavior cancels the road completely. There are also cases where roads bordering arable land become part of it. It is not known whether this is due to recklessness in working arable land, or from the desire to arbitrarily increase the plot of arable land, but such a case, during the investigation, was observed on road no. 04-021 (Figure 10). 


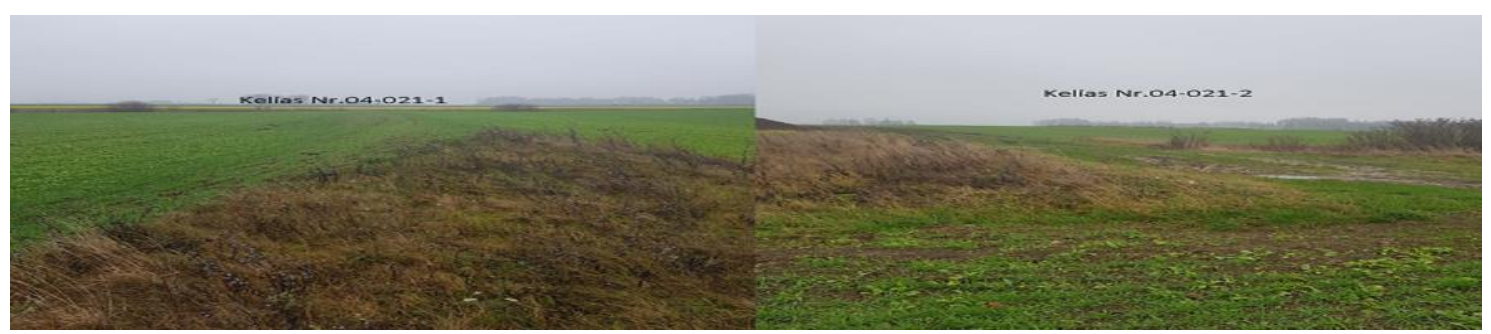

Figure 10. Road no. Excerpt 04-021 (photo by the authors)

The road and its fragment presented in the figure are solid according to the special plan of the communication system of Kairiai eldership. However, the image captured in reality shows that the middle of the road has become arable land and the area where the road should be is overgrown with grass. As the road no longer forms one plot, it was decided to divide it into two parts: no. 04-021-1 and no. 04-021-2. The formation of this road into two separate plots of land caused problems for the land appropriated by the farmer. In the second part of the road, this did not cause problems to form the road, but in the first part the road ended earlier than the road zone (Figure 11).

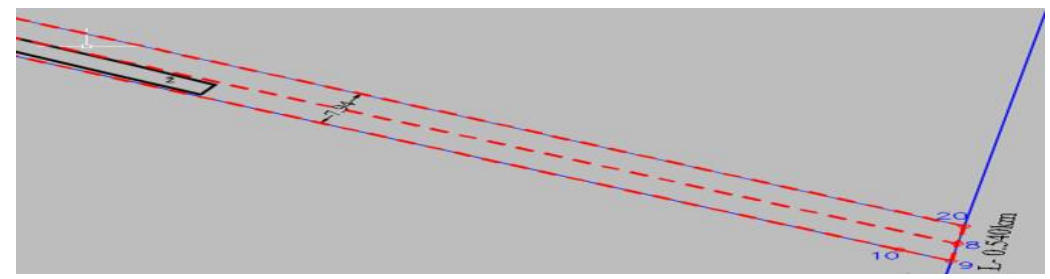

Figure 11. Result of cadastral measurements of road No.04-021-1

Among the registered plots of land is an area of land left for the road zone. Although there is no road there, the zone must be formed in accordance with the requirements. Examination of the land use planning projects of this area revealed that this road is 8 meters wide, which means that its zone $(7.94 \mathrm{~m})$ is formed correctly, as an error of $10 \mathrm{~cm}$ is applied.

In the following example, on road no. 04-008, the interference of the road lane with the registered plot of land is recorded. This is a common problem, but this time it is unique in that it happened on a straight stretch of road (Figure 12), which is not so common.

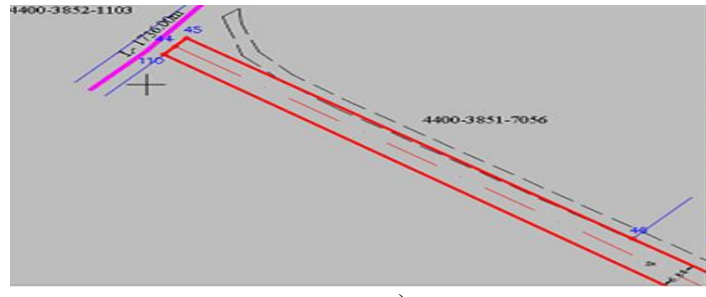

a)

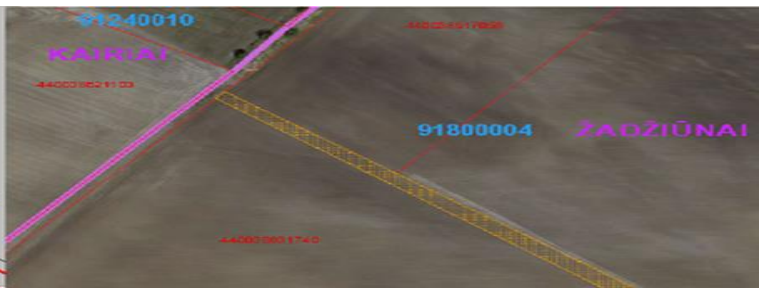

b)

Source: www. geoportal.lt

Figure 12. Road no. 04-008 cadastral measurement results (a) and orthophoto (b)

In this case, the road zone had to be formed on the basis of registered plots of land, regardless of the real situation. The surrounding cultivated fields are likely to be the reason why this road no longer enters the zone of its own plot. According to the orthophotographic material, it seems that there is no end of the road at all, but the results of cadastral measurements showed that this road still has an end, only it no longer enters its projected plot zone. To remedy this situation, cadastral measurements should be made on adjacent plots or the road should be overhauled to correct the location of the roadway.

The study found that sometimes problems also occur due to incorrectly determined boundaries or planning peculiarities of adjacent land plots. When designing roads, they usually have to be connected to registered plots of land so that the plots of land do not remain independent of anyone, but there are cases where this can be problematic. Such an example is given in Figure 13.

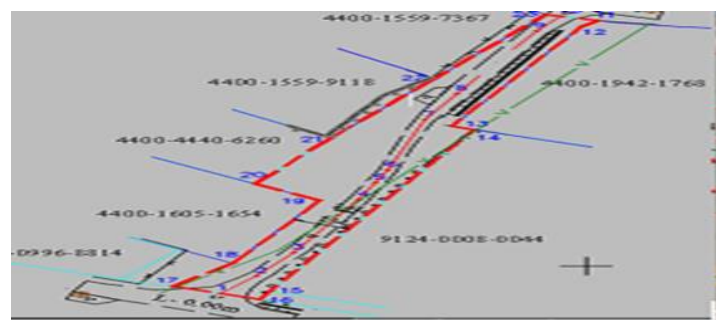

a)

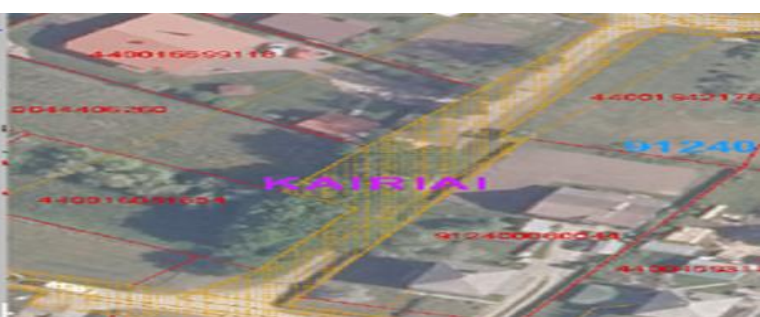

b)

Source: www.geoportal.lt

Figure 13. Road no. 04-011 measurement results (a) and orthophoto (b) () 
As can be seen, there are predominantly registered plots of land near the road, the layout of which is rather fragmented, which raises the question of how to deal with the determination of the road zone. Land use plans did not specify a set width for this road. This means that the planning work did not cover this road. After reaching this conclusion, it was chosen to align the road area with the existing land plots. In the present case, such a decision was taken because there would be no land left unused.

As is known, it is worthwhile to analyze the orthophotographic material in detail before making cadastral measurements. Such material allows for a better understanding of the real state of the object. After examining the latest aerial photographs, it is possible to prepare for outdoor cadastral measurements. However, wooded areas in this way are often difficult to explore, due to the crowns of trees that obscure the view from above. When performing cadastral measurements on the road no. 04-032, which extends through a small forest, an obvious discrepancy was observed, which is not visible from the orthophotographic photograph (Figure 14).

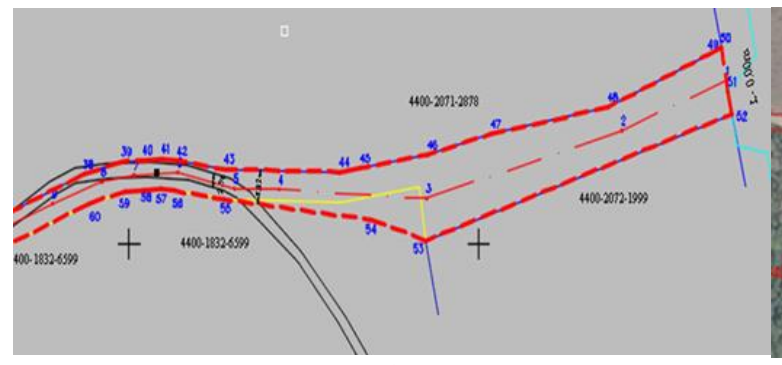

a)

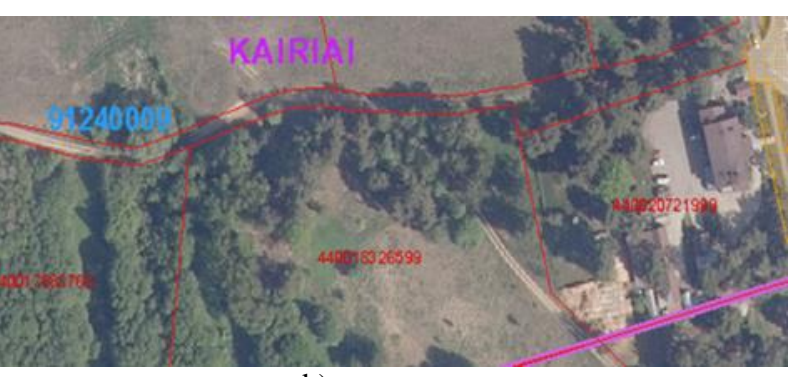

b)

Source: www.geoportal.1t

Figure 14. Road no. 04-032 measurement results (a) and orthophoto (b)

As can be seen, the road is overgrown with trees, in places the shades of the trees obstruct the object-road itself. However, due to the sharp contours of the road, it is possible to see in which direction this road leads. Using the data of the Real Estate Cadastre Map, a discrepancy was observed - part of the road does not correspond to the road area allocated to it at all. In this case, it was clear that it would not be necessary to perform cadastral measurements of the entire road, and its zone would have to be formed according to the adjacent land plots. To remedy this problem, the land area marked with cadastral number 4400/1832: 6599 should be re-measured with cadastral measurements and re-registered, as its boundaries no longer correspond to reality. Such road layout has been observed only once during the study, but due to the volatility of the local road network, such cases are more common.

Summarizing the results of the research it can be stated that as Kairiai eldership is a suburban area, it is likely that the need for local roads will only increase. However, at present, the condition of the roads of this eldership is good only at the more important objects, and the more remote Internal roads, which make up 27 per cent of the entire local road network of Kairiai eldership, are unfortunately in poor condition. When drawing up local road plans after cadastral measurements, discrepancies between the roadway and the road length in general, according to the available primary data, are most often encountered. The poor condition of the roads indicates that the funds allocated for the maintenance of these roads are insufficient or used inefficiently. The most promising way to avoid this is to create a kind of monitoring system that would allow monitoring the condition of roads and contribute to the planning of their management. It is also very important to oblige landowners to use and maintain existing plots of land properly.

\section{CONCLUSIONS}

1. After the analysis of the road network of Šiauliai district municipality it was established that the length of local roads is $1949 \mathrm{~km}$, of which public roads cover the length of $575.9 \mathrm{~km}$ and it makes up 31 per cent of all local roads, Internal roads cover $602.2 \mathrm{~km}$ (30 per cent) and streets cover $770.5 \mathrm{~km}$, i.e. 39 per cent of all local roads. As can be seen throughout the district, public and internal roads are practically evenly distributed, with a slightly larger share of streets than public and local roads. In the structure of the local road network in the district, Kuršenai city and Šiauliai rural elderships stand out the most. Kuršènai city eldership has no Internal roads, and public roads are only five, the total length of which is only $1.59 \mathrm{~km}$, but the length of all streets is $111.1 \mathrm{~km}$. Šiauliai rural eldership stands out as an eldership, where the length of all streets is the longest in the district and makes up as much as $223.7 \mathrm{~km}$.

2. The local road network of Kairiai eldership with public internal roads and all streets is $120 \mathrm{~km}$ long, of which the majority (37\%) is occupied by public roads, $26 \%$ - by streets and $27 \%$ - by Internal roads. Local significance Internal roads, according to the adjustment solutions of the Special Plan of the Transport System of Šiauliai district are $32.17 \mathrm{~km}$ long, of which $6.90 \mathrm{~km}$ are asphalt pavements, $15.80 \mathrm{~km}$ are gravel pavements, and $9.47 \mathrm{~km}$ are ground pavements. There are 38 local significance internal roads in the eldership. Their condition is very diverse.

3. Using the results of cadastral measurements and the inventory performed during them it was established that 29 local significance roads were not registered in Kairiai eldership. After performing cadastral measurements and drawing plans, it became clear that according to the municipal data, the total indicative length of these roads should be about 20.8 $\mathrm{km}$, and is $16.7 \mathrm{~km}$, i.e. $4.1 \mathrm{~km}$ discrepancy/deficiency detected. The condition of the local roads themselves is good only at the more important objects, and the more remote internal roads, which make up 27 per cent of the entire local road 
network of Kairiai eldership unfortunately are in poor condition. Also during the study, the analysis of territory planning documents and other primary planning material revealed that the following problems of road use are most common: poor road maintenance, improper road use, selfish connection of the road to the existing land plot and road interference with private land plots.

4. The results of the performed cadastral measurements have revealed that it would be expedient to create a certain monitoring system that would allow monitoring the condition of the roads and contribute to the planning of their management. It is also very important to oblige landowners to use existing land plots in an orderly manner. Local road management plans are needed with increased funding, as well as an obligation for landowners to use and maintain their land properly.

\section{REFERENCES}

1. Aleknavičius P. 2017. Factors influencing changes in the cultural agrarian landscape in Lithuania. Geology. Geography, Vol.. 3. No. 1, pp. 11-24 (in Lithuanian).

2. Aleknavičius P. 2012. Territorial administration and law. Akademija, Kaunas, University of Aleksandras Stulginskis (in Lithuanian).

3. Gasilionis A. 2001. Problems of land cadastre formation. Geodesy and Cartography, Vol. 27, No.1, pp. 40-43. Interactive: (in Lithuanian).

4. Keller G., Sherar J. 2003. Low-volume roads engineering. Californija. 117 p. Interactive: https://vtechworks.lib.vt.edu/bitstream/handle/10919/68420/LowVolumeRoadsEngineering.pdf?sequence=1\&isAllowed=y

5. Kryževičienė N. 2016. Roads of local significance. How to maintain and develop properly. Let's fix the road, No 5, p. 2. Interactive: http://www.keliaiirtiltai.lt/biblioteka/2016-06-nr-5-taisom-kelia/ (in Lithuanian).

6. Order of the Director of the Lithuanian Road Administration under the Ministry of Transport and Communications in 2016, May 4 No. V-258. Regarding the identification of defects (damages) of local roads (streets) and approval of recommendations for the selection of the type of construction works. Interactive: https://e seimas.lrs.lt/portal/legalAct/lt/TAD/a409da40123311e6aa14e8b63147ee94?jfwid=q86m1vqqw (in Lithuanian).

7. Moser V., Barišić I., Rajle D., Dimter S. 2016. Comparison of different survey methods data accuracy for road design and construction. Cetra 2016: 4th international conference on road and rail infrastructure, pp. 23 - 25, 2016.

8. Parseliunas E., Buga A., Marozas L., Petniunas M., Urbanas S. 2008. LitPOS - A part of EUPOS. GEODESY AND CARTOGRAPHY,Vol. 34, No.2, pp. 50-57. https://doi.org/10.3846/1392-1541.2008.34.50-57

9. Petkevičienė B., Petkevičius K. 2006. Landscape geography. The most important features of the development of road improvements in the Lithuanian landscape. Geography, Vol. 42, No. 2, pp. 65-73. (in Lithuanian).

10. Sivilevičius H., Sokolov J. 2011. Analysis of the interaction of heavy vehicles with the road surface and their influence on the layers of the structure. Science - the future of Lithuania, Vol. 3, No. 2, pp. 103-109. (in Lithuanian). https://doi.org/10.3846/mla.2011.040

11. Sivilevičius H. 2012. Elements of the transport system. Roads and their structures, 22 p. Vilnius: VGTU Publishing House Technika. VGTU leidyklos Technika .(in Lithuanian).

12. Skeivalas J. 2006. Covariation of ionospheric influence after GPS measurements. Geodesy and cartography, Vol. 32, No.1, pp. 35. (in Lithuanian).

13. Šiauliai District Municipal Council. Šiauliai District Municipality Strategic Development Plan for 2017-2023. Interactive: http://195.182.89.44/aktai/Default.aspx?Id=3\&DocId=41217\#_Toc463453256 (in Lithuanian).

14. Tamošauskas S., Pocius S. 2008. Local Roeads. Kaunas, Ardiva. (in Lithuanian).

15. Free Encyclopedia, 2007. Interactive: https://lietuvai.lt/wiki/\%C5\%A0iauli\%C5\%B3_kaimi\%C5\%A1koji_seni\%C5\%ABnija (in Lithuanian).

16. Lithuanian Spatial Information Portal, www.geoportal.lt. Interactive: https://www.geoportal.lt/geoportal/ (in Lithuanian.)

17. Adjustment of the special plan of the communication system in Šiauliai district. Formation of general solutions, 2018a. Interactive: https://www.siauliuraj.lt/data/public/uploads/2019/12/ar_koncepcija.pdf (in Lithuanian).

18. Adjustment of the special plan of the communication system in Šiauliai district. Solutions. Kairiai eldership, 2018b. Interactive: https://www.siauliuraj.lt/data/public/uploads/2019/12/8_kairiu_seniunija_sprendiniai.pdf (in Lithuanian). 